\title{
Medzinárodná vedecká konferencia: 6. slovensko-české stretnutie doktorandov a postdoktorandov v odbore právnych dejín a rímskeho práva, Trnava, 2018
}

V dňoch 31. 5. - 1. 6. 2018 sa na pôde Právnickej fakulty Trnavskej univerzity v Trnave uskutočnil už v poradí 6. ročník tradične medzi fakultami „,kolujúceho“ podujatia - stretnutie doktorandov a postodoktorandov slovenských a českých právnických fakúlt, venujúcich sa oblasti právnej histórie, resp. teórie a dejín štátu a práva a rímskeho práva. Zmyslom týchto každoročných stretnutí - súčasné trnavské nevynímajúc - je stretávanie sa kolegov z celého bývalého Československa, vzájomné poznávanie sa, odovzdávanie si skúseností a, pravdaže, prezentácia výsledkov vlastného bádania a tvorivého úsilia adeptov právnohistorickej a romanistickej vedy, spojená s plodnou a obohacujúcou diskusiou. S týmto zámerom k príprave medzinárodnej vedeckej konferencie pristúpili aj jej organizátori z Katedry právnych dejín Právnickej fakulty TU v Trnave pod taktovkou doc. JUDr. PhDr. Adriany Švecovej, PhD. Vedeckej garancie konferencie sa ujali prof. JUDr. Dr. h. c. Peter Mosný, CSc. (Právnická fakulta TU v Trnave), prof. JUDr. Ladislav Vojáček, CSc. (Právnická fakulta MU v Brne) a prof. JUDr. PhDr. Tomáš Gábriš, PhD., LL.M., M.A. (Právnická fakulta UK v Bratislave).

Prvý deň konferencie sa niesol v takpovediac neformálnom duchu, kedy sa účastníci konferencie v podvečerných hodinách postupne postretali v historickej Trnave a strávili spolu príjemný spoločenský večer spojený s exkurziou po meste. Druhý deň konferencie bol už prísne pracovný, venovaný vedeckému rokovaniu. Konferenciu otvorila pani dekanka Právnickej fakulty Trnavskej univerzity v Trnave, doc. JUDr. Mgr. Andrea Olšovská, $\mathrm{PhD}$., pod ktorej záštitou sa konferencia konala. Po srdečnom príhovore venovala niekol'ko slov spomienke na zosnulého prof. JUDr. Petra Blaha, CSc., dlhoročného kolegu, pedagóga, vynikajúceho romanistu, spoluzakladatel'a Právnickej fakulty TU, neskôr rektora TU v Trnave. Účastníci konferencie hlboko dojatí touto stratou vzdali pánovi profesorovi úctu minútou ticha.

Po zahájení a pietnej spomienke nasledovala vlastná rokovacia čast’ konferencie. Organizátori na jej začiatok pripravili panelovú diskusiu na tému Vizia a budúcnost' právnych dejín. Prizvaní diskutéri (prof. Vojáček, prof. Gábriš, doc. Šošková, doc. Švecová, doc. Laclavíková, doc. Tauchen, doc. Lysý, doc. Vladár a Dr. Šejdl) sa spolu s prítomnými účastníkmi konferencie zamýšl'ali nad dôležitost'ou odboru právnych dejín a rímskeho práva a nad ich vysoko cenným prínosom pre súčasné pozitívne právo. Zhodli sa na potrebe posilňovania a určitej stabilizácie týchto odborov. V zásade vyjadrili myšlienku, že historický kontext možno hl'adat' pri každej právnej téme, právne dejiny sa v súčasnosti pretransformovali na právny realizmus, právnu sociológiu. Debatovali tiež o potrebe skúmat' 
ústavné dejiny, prelomové aspekty, fenomény (národný štát, parlamentarizmus a pod.), nakol'ko v strednej a východnej Európe máme k tomu jedinečnú skúsenost'. Prezentovali domnienku, že právne dejiny majú zmysel vtedy, ak sa budú sústred'ovat' na vývoj jednotlivých právnych inštitútov. Ak budú toto právni historici vediet' ponúknut’ pozitivistom, bude aj odbor rešpektovaný ako rovnocenný. Účastníci debaty sa zaoberali tiež myšlienkou reformy výučby právnych dejín a aktuálnou výzvou učit' právne dejiny predovšetkým v magisterskom stupni vysokoškolského štúdia. Táto téma rozprúdila širokú názorovú platformu, najmä pokial' ide o zachovanie propedeutického charakteru rímskeho práva a právnych dejín vo vzt'ahu k platnému pozitívnemu právu. Na záver bolo konštatované, že právne dejiny majú nepochybne svoju budúcnost' zaistenú. Dôkazom je okrem iného i nastupujúca generácia tu prítomných právnych historikov a romanistov, ktorí vedia, že k právnej vede, ale najmä k zodpovednej tvorbe práva a jeho aplikácii v praxi bezpodmienečne patrí znalost' rímskeho práva a, prirodzene, orientovanie sa v právnych dejinách.

V rámci d’alšej vedeckej časti konferencie postupne odzneli do programu prihlásené príspevky účastníkov, rozdelené do celkovo štyroch blokov. Zazneli príspevky právnohistorické i romanistické, zamerané na súkromné i verejné právo, tiež na významné osobnosti a zvučné mená spojené najmä s česko-slovenskými i svetovými dejinami. Prirodzene, viaceré z príspevkov sa spájali s tohtoročným jubilejným výročím vzniku samostatnej ČSR. V snahe podporit' u čitatel'a záujem o pripravovaný konferenčný zborník, pokúsime sa v krátkosti priblížit' obsah jednotlivých vystúpení.

Ako prvý vystúpil prof. JUDr. PhDr. Tomáš Gábriš, PhD., LL.M., M.A. (PraF UK Bratislava) s príspevkom Americki Slováci a Pittsburská dohoda. Priblížil tento významný dokument takmer na deň presne v čase jeho 100. výročia vzniku. Na základe svojho bádania priamo v amerických archívoch predstavil Pittsburskú dohodu z mája 1918 ako jeden z revolučných programov spolužitia Čechov a Slovákov v samostatnom štáte, ozrejmil pozadie vzniku listiny, otázky jej platnosti a záväznosti, ako aj odkaz v neskoršom období (najmä v roku 1968, tiež v 90. rokoch 20. storočia). Mgr. Zuzana Illýová, PhD. (PraF UK Bratislava) predniesla príspevok nazvaný Význam Trianonskej mierovej konferencie pre vznik medzivojnovej Československej republiky. Cez dobové polemiky (názory Z. Pešku, L. Rašína, L. Buzu, S. Dnistrjanského) riešila vzt'ah Trianonskej mierovej zmluvy a momentu vzniku československého štátu, t. j. či táto zmluva mala konštitutívny alebo deklaratórny charakter. Konštatovala, že k deklaratórnemu charakteru mierovej zmluvy sa napokon priklonil aj Najvyšší súd ČSR a Najvyšší správny súd ČSR. Dominik Macek (PF UK Praha) venoval pozornost' postaveniu prvého prezidenta ČSR. V príspevku Tatíček Masaryk prezidentující. Postavení a pravomoce prvního čs. presidenta v diskusích a ústavách hodnotil sprvu len slabé reprezentatívne postavenie prezidenta, uvedomujúc si nedostatok demokracie v novom štáte. Autor predstavil „rodiaci sa“ status prezidenta ako otázku silne politickú, porovnával postupný vývoj od tzv. Prozatímnej ústavy 1918 k Ústavnej listine z roku 1920, zaoberal sa otázkou, či výpočet právomocí prezidenta bol taxatívny alebo exemplifikatívny. Mgr. Veronika Steinová (PF MU Brno) prezentovala svoj príspevok na tému Legislativní proces prijímáni zákonníku práce č. 65/1965 Sb. Uskutočnila historický exkurz do prameňov pracovného práva $\mathrm{v} 19$. storočí, prelomových zlepšení pracovných podmienok po roku 1918 v ČSR, zhodnotila absenciu kódexu pracovného práva prakticky až do druhej polovice 20. storočia. Priblížila podmienky prípravy, širokej verejnej diskusie a napokon prijatie prvého čsl. zákonníka práce účinného od 1. 1. 1966. V pomerne rozsiahlom, no prít’ažlivo 
spracovanom príspevku Cenzúra v slovenskom filme po roku 1968 opísal Mgr. Ján Šurkala, PhD. (PraF UK Bratislava) peripetie filmárskej slobody v 60. rokoch. Kým ich začiatkom bol umožnený vznik filmov vymykajúcich sa socialistickému realizmu a zameraných na dovtedy tabuizované témy, po vstupe vojsk Varšavskej zmluvy sa situácia výrazne zmenila. Autor predstavil dôvody vzniku Úradu pre tlač a informácie, Slovenského úradu pre tlač a informácie, rozobral definíciu a druhy cenzúry, hodnotil zavedenie tzv. vnútornej cenzúry podl'a sovietskeho vzoru, po federalizácii a nastolení normalizácie porovnal slovenskú cezúru s českou, a na konkrétnych filmoch demonštroval dôvody dobovej cenzúry.

Druhý blok konferencie zahájila JUDr. Alexandra Letková, PhD. (PraF UK Bratislava) s referátom Extrémizmus a historická pamät národa. Snažila sa odhalit', čo možno rozumiet' pod pojmami historická pamät', kolektívna pamät', v akom vzt’ahu sú historická pamät' a historické zabúdanie, ako tieto slúžia národu. Podružne sa zamýšl’ala tiež nad otázkou možných chýb a pochybení vo výučbe právnych dejín vo vzt’ahu k súčasnej mladej generácii. Apelovala na významnú rolu historikov a právnych historikov pri vysporiadávaní sa s historickými faktami, alternatívami, mýtmi či klamstvami. Ďalej Mgr. Lenka Martincová (PraF UK Bratislava) sa sústredila na Proces so Štefanom Polakovičom. V rámci svojho bádania zistila, že v archíve SAV, ani v archíve Bohosloveckej fakulty UK v Bratislave o Štefanovi Polakovičovi nie je jediná zmienka, absentuje jeho habilitačná práca i celý zamestnanecký spis. „Aj takýto bol Štefan Polakovič...“, odznelo z úst autorky. Následne poslucháčov previedla procesom, v ktorom bol Polakovič obžalovaný z národného socializmu, až po jeho odsúdenie L'udovým súdom v roku 1948. Referát na tému Trestní řizeni s bývalými ř́šskymi protektory Konstantinem von Neurathem a Wilhelmem Frickem v rámci Mezinárodního vojenského tribunálu v Norimberku predniesol Mgr. Jan Beránek (PF UK Praha). Ozrejmil postavenie a význam týchto nechválne známych nacistov, ich počínanie v Protektoráte Čechy a Morava, vylíčil tiež ich psychologický profil, a to všetko cez prizmu Norimberského tribunálu. Mgr. Katarína Bavlšíková (PraF UK Bratislava) v príspevku s priliehavým názvom Zdeněk Peška - život a dielo predstavila osobnost’ tohto významného univerzitného profesora, odborníka na ústavné právo, politika odsúdeného na 25 rokov trestu žalára v procese s Miladou Horákovou. Pozornost' venovala tiež jeho dielu, najmä jeho publikáciám venovaným menšinovým právam v Československu a československému jazykovému právu. Blok zakončila Mgr. Monika Mezulianíková (PF MU Brno) s príspevkom na tému Očista veřejné správy v letech 1945-1948 se zaměřením na prof. Zděnka Neubauera. V súvislosti s tzv. retribučnými dekrétmi z roku 1945 a na ich základe konaniami pred „očistnými““ komisiami (podliehali im štátni zamestnanci, učitelia a i. stíhaní pre asociálnost') priblížila osud mimoriadneho profesora Právnickej fakulty v Brne Zděnka Neubauera, významného predstavitel'a brnianskej normatívnej právnej školy, ktorý pre údajnú národnú nespol'ahlivost' prišiel o profesorskú hodnost' napriek skutočnosti, že v r. 1948 bol zbavený obžaloby.

V d'alšom bloku konferencie vystúpil Mgr. Milan Šimandl, Dis. (PF UK Praha) s príspevkom venovaným Spojení pražských měst v roku 1784, ktorým došlo k spojeniu prakticky do jedného Hlavního města Praha (Hauptstadt Prag) s jednotným magistrátom, spoločnou pokladnicou, majetkom a sídlom v Staromestskej radnici. Ozrejmil problematiku pretrvávajúceho právneho partikularizmu, existencie postranných práv, kompetenčných sporov, reforiem súdnictva a magistrátov, pričom reformu zhodnotil ako medzistupeň medzi feudálnym a moderným poňatím samosprávy, pri zvýšenom vplyve centrálnej vlády. Ďalší vystupujúci, Mgr. Matej Mlkvý, PhD. (PraF UK Bratislava) v príspevku nazvanom $K$ vývoju pojmu 
vlastníckeho práva na Slovensku sa zameral v tejto súvislosti na doktrinálny vývoj v zásade od Verbőczyho až po prvú ČSR. Demonštroval, že Verbőczy nepoužíval pojmy possessio, proprietas alebo dominium v pravom rímskoprávnom zmysle; von Jung zas - vychádzajúc z Kelemena - dominium plenum uznával len vtedy, ak niekto držal civilne i naturálne zároveň. Autor odhalil tiež prvé použitie označenia „reivindikačná žaloba“ v uhorskom práve a priblížil nakladanie s týmto pojmom v uhorskej judikatúre na prelome 19. a 20. storočia. Nasledovala téma zameraná na oblast' obligačných vzt’ahov a otázku nadmerného poškodenia, resp. neúmerného ukrátenia predávajúceho (známeho z rímskeho práva ako laesio enormis). Účastníkov konferencie ňou previedla Mgr. Viktória Marková (PraF UK Bratislava) vo svojom referáte s názvom Komparácia právnej úpravy inštitútu laesio enormis vo vybraných právnych poriadkoch. Ozrejmila vzt'ah tohto inštitútu k tzv. laesio enormissima, ktorá v porovnaní so svetským právom vychádza z učenia kanonikov. Analyzovala podmienky prísažného a bezprísažného zrieknutia sa nárokov zo zmluvy v zmysle kanonického práva, definovala stupne nepomeru protiplnení a predstavila tiež dobovú prax súdov v Rote a Granade, pričom premostila k rozhodovacej praxi súdov v súčasnom Nemecku.

Posledný blok konferencie zahájil svojim romanistickým príspevkom na tému Vymezeni šire oprávnění usufruktuáře Mgr. Marek Novák (PF UK Praha). Uskutočnil híbkovú analýzu požívacieho práva (ius fruendi), skúmal z rôznych aspektov jeho obsah, podmienky nadobudnutia práv a povinností usufruktuára. Argumentáciou na základe fragmentov z Digest a Institutiones rozobral viaceré špecifiká iuris fruendi vo vzt'ahu napr. k mlád'atám zvierat, k výsledkom otrokovej práce alebo jeho služby, či iným špecifickým plodom. Antickým Rímom nás previedol i JUDr. Martin Gregor (PraF UK Bratislava) priblížiac z hl'adiska vývoja Právny postih korupcie v obdobi Rímskej republiky. Poslucháčov svojim prednesom doslova vtiahol do problematiky korupcie, pri ktorej Rimania nemali jednotnú skutkovú podstatu. Poznali a postihovali volebnú korupciu, tzv. ambitus (označovali tak korupciu, ale aj samotnú volebnú kampaň). Autor uskutočnil prierez právnej úpravy postihovania korupcie od počiatkov republiky až po jej krízové obdobie na prelome tisícročí, kedy konštatoval, že l'ud už korupciu vnímal ako „normálny štandard“. Posledným príspevkom rokovaciu čast' celodennej konferencie uzavrela JUDr. Ingrid Lancová (PF TU Trnava). Ponúkla Pohl’ad na eutanáziu v československom práve. Kým v stredoveku bola eutanázia vnímaná ako samovražda, novoveké názory ju považovali za osobitý trestný čin. Autorka priblížila vývoj právnych názorov a právne zakotvenie tohto inštitútu v uhorskom trestnom práve, neskôr v československých unifikačných návrhoch z rokov 1926 a 1937. Úpravu eutanázie následne hl'adala v čs. trestných kódexoch druhej polovice 20. storočia, naznačila súčasný trestnoprávny problém eutanázie a asistovanej samovraždy v zmysle platného práva v Slovenskej republike a v Českej republike. Predstavila tiež zaujímavé návrhy de lege ferenda a inšpirácie zo súčasného nemeckého trestného zákona.

Záver konferencie bol plný dojmov z príjemného stretnutia, milého pohostenia, plodnej vedeckej atmosféry a podnetných diskusií na rôznorodé témy. Dovolím si v mene všetkých zúčastnených pod'akovat' organizátorom za skutočne vydarené podujatie a vyjadrit' presvedčenie, že v tradícii každoročných stretnutí romanistov a právnych historikov spolu s ich šikovnými študentmi a absolventmi doktorandského štúdia chceme všetci pokračovat'.

doi: $10.14712 / 2464689 X .2018 .64$

Ivana Šošková 